\title{
Pelaksanaan Kesepakatan Diversi Pada Tingkat Penyidikan Dalam Sistem Peradilan Anak
}

\author{
Rina Nurhaliza, Herry Liyus, Dheny Wahyudi \\ Fakultas Hukum, Universitas Jambi, Indonesia \\ Author’s Email Correnspondence: rinanurhaliza17@gmail.com
}

\begin{abstract}
ABSTRAK
Artikel ini membahas pelaksanaan kesepakatan diversi pada tingkat penyidikan dalam sistem peradilan pidana. Penelitian ini bersifat yuridis empiris. Hasil penelitian menunjukkan bahwa pelaksanaan kesepakatan diversi pada tingkat penyidikan belum berjalan dengan baik dikarenakan (1) Sulitnya untuk mendapatkan kesepakatan kedua pihak; (2) Sulitnya mempertemukan kedua belah pihak dalam proses diversi; (3) Lalainya pelaku dalam melaksanakan pembayaran ganti rugi kepada korban; (4) Permintaan ganti rugi yang besar. Kendala yang ditemui dalam pelaksanaan kesepakatan diversi yang paling utama dilakukan oleh pihak yang bersangkutan yaitu lalainya pihak pelaku dalam membayar ganti kerugian.
\end{abstract}

Kata Kunci: Diversi; penyidikan; sistem peradilan pidana

\section{ARTICLE HISTORY}

Submission: 21 November 2019

Accepted: 03 February 2020

Publish: 07 February 2020

KEYWORDS: Diversion; investigation; criminal justice system

\begin{abstract}
This article discusses the implementation of diversion agreements at the level of investigation in the criminal justice system. Quite a lot of diversion processes reach agreement at the investigation level, but not all agreements are carried out as expected. This research is empirical juridical. The results showed that the implementation of the diversion agreement at the investigation level had been going well and in accordance with Law concerning the Child Criminal Justice System but there are still shortcomings in terms of implementation by the parties concerned. The obstacle encountered in implementing the diversion agreement is the main one carried out by the parties concerned, namely the failure of the perpetrators to pay compensation.
\end{abstract}

\section{A. Pendahuluan}

Artikel ini membahas tentang proses pelaksanaan kesepakatan diversi yang terjadi pada tingkat penyidikan dengan peraturan yang berlaku pada saat ini. Pelaksanaan diversi pada tingkat penyidikan berdasarkan Undang-Undang Nomor 11 Tahun 2012 tentang Sistem Peradilan Pidana Anak dan Peraturan Pemerintah Nomor 65 Tahun 2015 tentang Pedoman Pelaksanaan Diversi dan Penanganan Anak yang belum Berumur 12 Tahun.

Anak yang berhadapan dengan hukum (ABH) yakni anak yang melakukan tindak pidana dan anak yang melakukan perbuatan yang terlarang bagi anak, baik menurut perundang-undangan maupun menurut peraturan hukum lain yang berlaku dalam 
masyarakat yang bersangkutan. ${ }^{1}$ Sehingga harus mendapatkan sanksi yang sesuai atas apa yang telah dilakukannya. Sanksi yang diberikan kepada anak yang berhadapan dengan hukum harus tetap mempertahankan hak-hak anak dan melindungi hak-hak anak tersebut. Anak yang berhadapan dengan hukum merupakan bagian dari masyarakat yang tidak berdaya baik secara fisik, mental dan sosial sehingga dalam penanganannya perlu perhatian khusus agar menjadi pribadi yang lebih baik lagi. ${ }^{2}$

Sistem peradilan pidana anak merupakan segala unsur sistem peradilan pidana yang terkait di dalam penanganan kasus-kasus ABH. Polisi, Kejaksaan dan Pengadilan serta Pembimbing Kemasyarakatan atau Balai Pemasyarakatan, Advokat atau pemberi bantuan, Lembaga Pembinaan Khusus Anak (LPKA), Lembaga Penempatan Anak Sementara (LPAS) dan Lembaga Penyelenggaraan Kesejahteraan Sosial (LPKS) sebagai institusi atau lembaga yang menagani $\mathrm{ABH}$ mulai dari anak bersentuhan dengan sistem peradilan, menentukan apakah anak akan dibebaskan atau diproses ke pengadilan anak hingga tahapan ketika anak akan ditempatkan dalam pilihan-pilihan, mulai dari dibebaskan sampai dimasukkan dalam institusi penghukuman dalam koridor keadilan restoratif. ${ }^{3}$ Menurut Muladi, Restorative Justice atau keadilan restorative adalah sebuah teori yang menekankan pada memulihkan kerugian yang disebabkan atau ditimbulkan oleh perbuatan pidana. ${ }^{4}$

Penyelesaian perkara pidana anak dapat dilakukan melalui proses didalam pengadilan maupun diluar pengadilan. Penyelesaian perkara pidana anak melalui proses pengadilan yang akan berujung pada pemidanaan dijadikan upaya terakhir, sehingga lebih diutamakan untuk penyelesaian diluar pengadilan selama tindak pidana yang dilakukan oleh anak tidak merupakan tindak pidana berat. Penyelesaian diluar pengadilan dikenal dengan restorative justice yaitu bentuk yang paling disarankan dalam melakukan diversi terhadap anak yang berhadapan dengan hukum. Hal ini dikarenakan konsep restorative justice melibatkan berbagai pihak untuk menyelesaikan suatu permasalahan yang terkait dengan tindak pidana yang dilakukan oleh Anak. ${ }^{5}$

Dalam Undang-Undang Nomor 11 Tahun 2012 Tentang Sistem Peradilan Pidana Anak menyebutkan bahwa, diversi adalah pengalihan penyelesaian perkara anak dari proses peradilan pidana ke proses di luar peradilan pidana dengan berbasis keadilan restoratif. Proses diversi dilakukan melalui musyawarah dengan melibatkan anak dan orang tua/walinya, korban dan/atau orangtua/walinya, pembimbing kemasyarakatan, dan pekerja sosial profesional berdasarkan pendekatan keadilan restoratif. Selain itu juga, dalam hal diperlukan, musyawarah tersebut juga dapat melibatkan tenaga

Bambang Waluyo, "Pidana dan Pemidanaan”, Cet. 2, Sinar Grafika, Jakarta, 2004, hlm. 106.

Maidin Gultom, "Perlindungan Hukum Terhadap Anak (dalam Sistem Peradilan Pidana Anak di Indonesia)", Cet. 4, PT. Refika Aditama, Bandung, 2014, hlm. 77.

3 Riska Vidya Satriani, "Keadilan Restoratif Sebagai Tujuan Pelaksanaan Diversi Pada Sistem Peradilan Pidana Anak", https://www.mahkamahagung.go.id/id/artikel/ 2613/keadilanrestoratif-sebagai-tujuan-pelaksanaan-diversi-pada-sistem-peradilan-pidana-anak, di akses pada hari Jum'at tanggal 04 Desember 2018 pukul 13.48.

4 Muladi, Kapita Selekta Hukum Pidana, Semarang: Penerbit Universitas Diponegoro, 1995, hlm. 125.

5 Pangestika Rizki Utami, Konsep Diversi Dan Restorative Justice Sebagai Pergeseran Tanggung Jawab Pidana Pada Sistem Peradilan Pidana Anak, IAIN Purwokerto, 2018, hlm. 103. 
kesejahteraan sosial, dan/atau masyarakat. ${ }^{6}$ Diversi bertujuan agar perkara anak bisa diselesaikan dengan perdamaian sehingga anak tidak perlu menjalani hukuman lewat peradilan. Penerapan diversi dapat dilakukan di dalam semua tingkatan pemeriksaan yaitu penyidikan, penuntutan, dan pemeriksaan perkara anak di Pengadilan Negeri, hal ini dimaksudkan untuk mengurangi dampak negatif keterlibatan anak dalam proses peradilan tersebut. ${ }^{7}$ Yang melibatkan lembaga-lembaga kepolisian, kejaksaan, pengadilan dan pemsyarakatan terpidana. ${ }^{8}$

Penyelesaian perkara diversi dilakukan dengan musyawarah diversi yang bertujuan untuk mendapatkan perdamaian. Menurut PERMA No 4 tahun 2014, Musyawarah Diversi adalah musyawarah antara pihak yang melibatkan Anak dan orang tua/wali, korban dan/atau orang tua/walinya, Pembimbing Kemasyarakatan, Pekerja Sosial Profesional, perwakilan dan pihak-pihak yang terlibat lainnya untuk mencapai kesepakatan diversi melalui pendekatan keadilan restoratif.

Menurut pasal 10 UU No. 11 Tahun 2012 tentang Sistem Peradilan Pidana Anak, Kesepakatan Diversi dapat berbentuk:

a. Pengembalian kerugian dalam hal ada korban

b. Rehabilitasi medis dan psikososial

c. Penyerahan kembali kepada orang tua/Wali

d. Keikutsertaan dalam pendidikan atau pelatihan di lembaga pendidikan atau LPKS paling lama 3 (tiga) bulan

e. Pelayanan masyarakat paling lama 3 (tiga) bulan.

Apabila dalam dalam hal proses diversi berhasil mencapai kesepakatan, penyidik menyampaikan berita acara diversi kepada pengadilan negeri untuk dibuat penetapan. Sedangkan apabila diversi gagal, maka penyidik wajib melanjutkan penyidikan dan melimpahkan perkara ke penuntut umum dengan melampirkan berita acara diversi dan laporan penelitian kemasyarakatan. ${ }^{9}$

Tabel 1

Data Jumlah Perkara Anak di Polres Kerinci Tahun 2016 S/D 2018

No Tahun Jumlah Perkara Keterangan

\begin{tabular}{lllll}
\cline { 3 - 4 } & & Diversi & Tidak Diversi \\
\hline 1 & 2016 & 14 & 4 & 10
\end{tabular}

6 M. Nasir Jamil, "Anak Bukan Untuk Dihukum”, Cet. 2, Sinar Grafika Offset, Jakarta, 2013, hlm. 140.

7 Sri Rahayu, "Diversi Sebagai Alternatif Penyelesaian Perkara Tindak Pidana Yang Dilakukan Anak Dalam Perspektif Sistem Peradilan Pidana Anak", Jurnal Ilmu Hukum, Jambi, 2015, hlm.133.

8 Marjono Reksodipuro, "Sistem Peradilan Pidana Indonesia (Melihat Pada Kejahatan Dan Penegakan Hukum Dalam Batas-Batas Toleransi", Pidato Pengukuhan Penerimaan Jabatan Guru Besar Tetap Dalam Ilmu Hukum Pada Fakultas Hukum Universitas Indonesia, Jakarta, 1993, Hlm. 1. dikutip dari Kadri Husin dan Budi Rizki Husin, "Sistem Peradilan Pidana di Indonesia", Cet. 1, Sinar Grafika, Jakarta, 2016, hlm. 12.

9 Dahlan Sinaga, "Penegakan Hukum Dengan Pendekatan Diversi", Nusa Media Yogyakarta, Yogyakarta, 2017, hlm. 135. 


\begin{tabular}{lllll}
\hline 2 & 2017 & 8 & - & 8 \\
\hline 3 & 2018 & 7 & 2 & 5 \\
\hline & Jumlah & 29 & 6 & 23
\end{tabular}

Pada tabel 1 terdapat data jumlah perkara pidana anak yang ditangani di Polres Kerinci, terdapat 6 (enam) perkara pidana yang diselesaikan melalui diversi dan 23 perkara pidana anak yang tidak dilakukan upaya diversi. Alasan tidak dilakukannya proses diversi pada beberapa perkara tindak pidana anak tersebut dikarenakan tindak pidana yang dilakukan anak tidak memenuhi syarat untuk dilakukannya upaya diversi, kerugian yang diakibatkan anak cukup besar, dan ketidaksediaan pihak korban untuk melakukan proses diversi.

Diversi yang dilakukan penyidik terhadap perkara anak diatas mencapai kesepakatan akan tetapi terdapat kelalaian dalam proses pelaksanaan kesepakatan diversi. Kesepakatan yang diperoleh dari proses diversi mengandung unsur ganti rugi yang harus dilaksanakan oleh pihak yang bersangkutan. Didalam undang-undang tidak dijelaskan secara eksplisit bagaimana proses ganti rugi dalam diversi, hanya saja dijelaskan bentuk kesepakatan diversi saja. Ini menjadi salah satu hal yang harus diperhatikan oleh penegak hukum dalam melaksanakan diversi.

Kendala dalam proses pelaksanaan kesepakatan diversi ini tentunya dapat berdampak pada kegagalan proses diversi yang telah dilakukan, sehingga perlu adanya pengaturan lebih jelas tentang pelaksanaan kesepakatan diversi. Berdasarkan penjelasan diatas, artikel ini membahas mengenai bagaimana pelaksanaan kesepakatan diversi pada tingkat penyidikan dan Kendala yang dihadapi dalam proses pelaksanaan kesepakatan diversi pada tingkat penyidikan di Polres Kerinci.

\section{B. Metode Penelitian}

Penelitian ini menggunakan yuridis empiris adalah penelitian hukum mengenai setiap peristiwa hukum tertentu yang terjadi dalam masyarakat dengan Teknik pengumpulan data yang digunakan melalui wawancara dan observasi.

\section{Pembahasan}

\section{Diversi Sebagai Restorative Justice}

Keadilan restorative merupakan penyelesaian perkara pidana dengan pelaku anak dengan melibatkan pihak-pihak terkait demi mencari penyelesaian di luar pengadilan dengan prinsip pemulihan keadaan dan bukan pada tujuan membalaskan perbuatan pelaku dengan pidana penjara. ${ }^{10}$ Keadilan restorative berpijak pada hubungan yang manusiawi antara korban dan pelanggar dan fokusnya pada dampak yang ditimbulkan oleh kejahatan pada semua pihak, bukan hanya korban, tetapi juga pada masyarakat dan pelanggar sendiri. ${ }^{11}$ Restorative justice dikenal sebagai konsep

10 Hafrida, Yulia Monita, Elisabeth Siregar, "Pembinaan Narapidana Anak Di Lembaga Pemasyarakatan Anak. Sei. Bulu Muara Bulian (Kajian Terhadap Proses Penyelesaian Perkara Pidana Anak Tanpa Pidana Penjara (Diversi) Menurut Undang-Undang Nomor 11 Tahun 2012 Tentang Sistem Peradilan Pidana Anak)," Jurnal Publikasi Pendidikan, September 2015, hlm. 202.

11 F. Willem Saija dan Budi Suhariyanto, "Laporan Penelitian (Pelaksanaan Diversi Di Tingkat Pengadilan Negeri Dalam Sistem Peradilan Pidana Anak)”, 2016, hlm. 17. 
pemidanaan yang bermaksud untuk menemukan jalan untuk menegakkan sistem pemidanaan yang lebih adil dan berimbang, dengan memperhatikan kepentingan pelaku dan korban sebagai mekanisme untuk mencapai tujuan yang diselesaikan dengan perdamaian.

Dalam penjelasan umum Undang Undang Nomor 11 Tahun 2012 disebutkan: Keadilan restoratif merupakan suatu proses diversi, yaitu semua pihak yang terlibat dalam suatu tindak pidana tertentu bersama-sama mengatasi masalah serta menciptakan suatu kewajiban untuk membuat segala sesuatunya menjadi lebih baik dengan melibatkan korban, anak, dan masyarakat dalam mencari solusi untuk memperbaiki, rekonsiliasi, dan menentramkan hati yang tidak berdasarkan pembalasan. Tujuan utama restorative justice adalah perbaikan luka yang diakibatkan perbuatannya, dan konsiliasi serta rekonsiliasi di kalangan korban, pelaku, dan masyarakat.12 Dalam hal ini restorative justice membantu mengembalikan ke keadaan semula dengan tidak berpihak kepada korban maupun pelaku berdasarkan pada keinginan korban dan pelaku.

Kemudian terkait dengan ini salah satu bentuk dalam restorative justice adalah diversi terhadap anak yang berhadapan dengan hukum. Diversi merupakan wewenang dari aparat penegak hukum yang menangani kasus tindak pidana untuk mengambil tindakan meneruskan perkara atau menghentikan perkara, mengambil tindakan tertentu sesuai dengan kebijakan yang dimilikinya. ${ }^{13}$ Akan tetapi penegak hukum harus mengupayakan diversi disetiap perkara pidana anak yang memenuhi syarat untuk dilakukan upaya diversi.

Upaya diversi harus dilakukan di semua tingkatan yaitu pada tingkat penyidikan, penuntutan, dan pemeriksaan perkara anak di pengadilan negeri. Diversi tidak wajib dilaksanakan apabila anak yang menjadi pelaku tindak pidana diancam dengan pidana penjara diatas 7 (tujuh) tahun dan merupakan pengulangan tindak pidana (residivis). Sebagaimana yang telah diatur dalam Pasal 7 ayat (1) dan (2) Undang-Undang Sistem Peradilan Pidana Anak. Maksud dari tidak wajib dilaksanakan diversi adalah tidak bersifat imperatif atau fakultatif, yang artinya perkara anak yang tindak pidananya diancam pidana penjara di atas 7 (tujuh) tahun atau merupakan pengulangan tindak pidana, dapat saja diupayakan diversi. ${ }^{14}$

Kemudian terkait dengan ini salah satu bentuk dalam restorative justice adalah diversi terhadap anak yang berhadapan dengan hukum. Berdasarkan pada United Nations Standard Minimum Rules for the Administration of Juveniles Justice (The Beijing Rules), Ide diversi dicanangkan dalam United Nation Standart Minimum Rules for the Administration of Juvenile Justice (SMRJ) atau The Beijing Rules (Resolusi Majelis PBB 40/33 tanggal 29 November 1985), dimana diversi tercantum dalam Rule 11.111 .2 dan Rule 17.4.

Diversi adalah pemberian kewenangan kepada aparat penegak hukum untuk mengambil tindakan-tindakan kebijaksanaan dalam menangani atau menyelesaikan

12 Nur Rochaeti, "Implementasi Keadilan Restoratif Dan Pluralisme Hukum Dalam Sistem Peradilan Pidana Anak Di Indonesia", Hasil Penelitian, Fakultas Hukum Diponegoro, Semarang, 2015, lm. 153.

13 Marlina, "Pengantar Konsep Diversi dan Restorative Justice dalam Hukum Pidana”, Medan, USU Press, hlm. 1.

14 R. Wiyono, "Sistem Peradilan Pidana Anak di Indonesia”, Cet. 1, Sinar Grafika Offset, Jakarta, 2016, hlm. 51. 
masalah pelanggar anak dengan tidak mengambil jalan formal antara lain menghentikan atau meneruskan atau melepaskan dari proses peradilan pidana atau mengembalikan atau menyerahkan kepada masyarakat dan bentuk-bentuk kegiatan pelayanan sosial lainnya. ${ }^{15}$ Oleh karena itu terdapat suatu kebijakan penegak hukum untuk melanjutkan atau menghentikan perkara pidana anak tersebut.

Konsep diversi pertama kali dikemukakan sebagai kosakata pada laporan peradilan anak yang disampaikan Presiden Komisi Pidana (President's crime commissionis) Australia di Amerika Serikat pada tahun 1960. Awalnya konsep diversi telah ada sebelum tahun 1960. Awalnya konsep diversi telah ada sebelum tahun 1960 ditandai berdirinya peradilan anak (children's court) sebelum abad ke-19 yaitu diversi dari sistem peradilan pidana formal dan formalisasi polisi untuk melakukan peringatan (police cautioning). Prakteknya telah berjalan di Negara bagian Victorian Australia pada tahun 1959 diikuti oleh negara bagian queensland pada tahun 1963.16

Diversi menjadi solusi bagi anak yang melakukan tindak pidana agar terhindar dari proses peradilan dan untuk menghindari adanya pemidanaan terhadap tindak pidana yang telah dilakukan. Hal ini ditekankan agar posisi anak sebagai makhluk manusia harus mendapatkan perlindungan atas hak-hak yang dimilikinya. ${ }^{17}$

\section{Kesepakatan Diversi}

Pasal 1 angka 4 Peraturan Mahkamah Agung Nomor 4 tahun 2014 menyatakan bahwa Kesepakatan Diversi adalah kesepakatan hasil proses musyawarah Diversi yang dituangkan dalam bentuk dokumen dan ditandatangani oleh para pihak yang terlibat dalam musyawarah Diversi. Kesepakatan diversi harus mendapatkan persetujuan dari korban dan/atau keluarganya serta kesediaan anak dan keluarganya. Hal ini menunjukkan bahwa pentingnya keaktifan pihak korban serta pelaku dalam proses keberhasilan diversi. Akan tetapi kesepakatan diversi juga bisa tanpa persetujuan dari pihak korban atau keluarganya jika tindak pidana yang dilakukan berupa pelanggaran, tindak pidana ringan, tindak pidana tanpa korban, dan nilai kerugian tidak lebih dari upah minimum provinsi setempat. Kesepakatan tanpa persetujuan korban atau keluarganya dilakukan oleh penyidik bersama pelaku dan/atau keluarganya, pembimbing kemasyarakatan, serta dapat melibatkan tokoh masyarakat.

Kesepakatan diversi dapat berbentuk pengembalian kerugian dalam hal ada korban, rehabilitasi media dan psikososial, keikutsertaan dalam pendidikan atau pelatihan di lembaga pendidikan atau LPKS paling lama 3 (tiga) bulan atau pelayanan masyarakat paling lama 3 (tiga) bulan.

Berdasarkan Pasal 11 UU No. 11 Tahun 2012 tentang Sistem Peradilan Pidana Anak bahwa hasil kesepakatan diversi dapat berbentuk antara lain:

a. Perdamaian dengan atau tanpa ganti kerugian;

b. Penyerahan kembali kepada orang tua atau wali;

c. Keikutsertaan dalam pendidikan atau pelatihan di lembaga pendidikan atau LPKS paling lama 3 (tiga) bulan; atau

Ibid., hlm. 47-48.

16 Willem Saija dan Budi Suhariyanto, Op. Cit., hlm. 9.

17 A. Basronni, "Pertanggungjawaban Pidana Yang Dilakukan Oleh Anak", http://eprints.ums.ac.id/52012/3/BAB\%201.pdf, di akses pada hari Selasa tanggal 15 Januari 2019 pukul 10.32 . 
d. Pelayanan masyarakat.

Akan tetapi masih dimungkinkan adanya hasil kesepakatan diversi selain daripada hasil kesepakatan diversi seperti yang telah disebutkan diatas. Hal ini tergantung pada apa yang diminta oleh korban dan apa yang disanggupi oleh pelaku.

Hasil kesepakatan diversi dituangkan dalam bentuk kesepakatan diversi yang ditandatangani oleh para pihak yang terlibat, kemudian oleh atasan langsung pejabat yang bertanggung jawab di setiap tingkat pemeriksaan disampaikan ke pengadilan dalam waktu paling lama 3 (tiga) hari sejak kesepakatan dicapai untuk memperoleh penetapan. ${ }^{18}$ Setelah memperoleh penetapan pihak yang terlibat mulai melaksanakan kesepakatan diversi sesuai dengan waktu dan kesepakatan yang telah ditetapkan serta telah ditandatangani.

Dalam hal kesepakatan diversi mensyaratkan adanya ganti kerugian atau pengembalian pada keadaan semula, maka kesepakatan diversi tersebut dilakukan dalam jangka waktu yang telah disepakati dalam diversi, namun tidak boleh melebihi 3 (tiga) bulan. Hasil kesepakatan diversi tersebut dituangkan dalam bentuk surat kesepakatan diversi. Dalam hal kesepakatan Diversi tidak dilaksanakan dalam jangka waktu yang telah ditentukan (terutama yang berkaitan dengan pembayaran ganti kerugian, pengembalian pada keadaan semula, atau pelayanan masyarakat), Pembimbing Kemasyarakatan melaporkan secara tertulis kepada atasan langsung Penyidik, Penuntut Umum, dan Hakim bahwa kesepakatan diversi tidak dilaksanakan serta dapat ditindaklanjuti dalam proses peradilan pidana dengan tembusan kepada Ketua Pengadilan Negeri setempat.

\section{Pelaksanaan Kesepakatan Diversi Pada Tingkat Penyidikan}

Penyidik yang menangani kasus anak adalah penyidik anak. Penyidik anak haruslah memenuhi syarat telah berpengalaman sebagai penyidik tindak pidana yang dilakukan oleh orang dewasa dan mempunyai minat, perhatian, dedikasi dan memahami masalah anak. ${ }^{19}$

Sebelum dilakukan proses diversi, penyidik mempertemukan pihak pelaku dan pihak korban. Dalam hal ini penyidik memberikan penjelasan mengenai diversi sebagai upaya untuk melakukan diversi kepada pihak korban dan pelaku apakah ingin melakukan proses diversi atau tidak. Penyidik menjelaskan mengenai bentuk dan tujuan diversi agar kedua belah pihak paham bahwa diversi semata-mata bukan hanya sekedar penyelesaian perkara secara damai dan menguntungkan sebelah pihak akan tetapi memperhatikan kedua pihak agar tidak saling merugikan. Dalam Pasal 6 UU SPPA, diversi memiliki tujuan sebagai berikut:
a. Mencapai perdamaian antara korban dan anak;
b. Menyelesaikan perkara anak di luar proses peradilan;
c. Menghindarkan anak dari perampasan kemerdekaan;
d. Mendorong masyarakat untuk berpartisipasi; dan
e. Menanamkan rasa tanggung jawab kepada anak.

18 R. Wiyono, Op. Cit., hlm. 57.

19 Lilik Mulyadi, "Pengadilan Anak di Indonesia (Teori, Praktik, dan Permasalahannya)", Cet. 1, Mandar Maju, Bandung, 2005, hlm. 30. 
Seperti yang dikemukakan oleh Ragil (Kanit PPA) Polres Kerinci bahwa: "Sebelum melakukan proses diversi penyidik mempertemukan pihak pelaku dan pihak korban untuk menanyakan kesediaan dari kedua belah pihak terutama pihak korban apakah bersedia untuk melaksanakan diversi atau tidak". ${ }^{20}$

Penyidik dalam hal ini tidak mengupayakan diversi berdasarkan kebijakan sendiri, namun karena kewajiban. Jika pihak korban dan pelaku bersedia dilakukan proses diversi maka penyidik menetapkan tanggal dimulainya musyawarah diversi dan mempersiapkan segala sesuatu yang diperlukan dalam proses diversi. Akan tetapi, jika pihak pelaku dan pihak korban tidak sepakat untuk melakukan diversi maka penyidik melanjutkan proses penyidikan dan kemudian menyampaikan berkas perkara kepada Penuntut Umum. Pelaksanaan proses diversi dilakukan pada waktu yang telah ditentukan dan pada tempat yang telah dipersiapkan oleh penyidik.

Dalam hal proses musyawarah diversi tidak mencapai kesepakatan, penyidik membuat laporan dan berita acara proses diversi serta mengirimkan berkas perkara kepada Penuntut Umum serta melanjutkan proses peradilan pidana. Jika proses musyawarah diversi berhasil mencapai kesepakatan, surat kesepakatan ditandatangani oleh para pihak yang terlibat dalam musyawarah diversi dan seluruh proses pelaksanaan diversi dicatat dalam berita acara diversi.

Kesepakatan diversi disahkan apabila telah disepakati oleh pihak korban dan pihak pelaku. Hasil kesepakatan diversi disampaikan oleh penyidik ke pengadilan negeri dalam waktu paling lama 3 (tiga) hari sejak kesepakatan dicapai untuk memperoleh penetapan. Di Polres Kerinci terdapat beberapa perkara pidana yang diselesaikan melalui diversi setelah adanya kesepakatan diversi dan memperoleh penetapan dari pengadilan, diantaranya:

Dari tahun 2016 sampai tahun 2018 terdapat 6 (enam) perkara pidana anak yang diselesaikan melalui diversi. Dalam 6 (enam) perkara pidana yang diselesaikan melalui diversi, semua isi kesepakatan hampir sama akan tetapi yang berbeda adalah bentuk ganti rugi sebagai pertanggungjawaban pelaku. Karena, bentuk tindak pidana yang dilakukan berbeda serta pertanggungjawabannya pun pastinya berbeda.

Ganti rugi yang diberikan pelaku tidak hanya berbentuk materil tetapi tergantung dari apa kerugian yang dialami oleh korban. Ganti rugi yang diberikan dapat berbentuk uang, biaya pengobatan dan berbentuk barang yang menjadi kerugian bagi korban. Hal ini tergantung pada apa yang telah disepakati antara korban dan pelaku.

Menurut penulis ganti rugi yang diberikan pihak pelaku kepada pihak korban sangat mempengaruhi keberhasilan proses diversi. Dengan adanya ganti rugi tersebut pihak korban akan merasa bahwa pelaku bertanggungjawab atas perbuatannya serta pihak korban tidak akan merasa terbebani atas kerugian yang pernah dialaminya karena tindak pidana yang dilakukan oleh pelaku.

Menurut Ragil (Kanit PPA) Polres Kerinci, Mengemukakan bahwa kedua belah pihak antara pelapor dan terlapor berhasil terselesaikan kasusnya dengan penyelesaiannya:

1. Terlapor harus meminta maaf kepada pelapor atau korban.

20 Wawancara Langsung, dengan IPTU RAGIL, Polres Kerinci, Selasa 8 Januari 2019. 
2. Terlapor berjanji untuk tidak mengulangi lagi kepada pihak pelapor atau korban.

3. Keluarga pelapor setuju dan sepakat dengan terlapor dikembalikan ke keluarganya.

4. Pelapor sepakat untuk diselesaikan secara kekeluargaan.

5. Terlapor mengganti biaya kerugian yang dialami pelapor atau korban. ${ }^{21}$

Kesepakatan hasil diversi yang telah disepakati dan diterima pada proses diversi, oleh penyidik akan disampaikan ke pengadilan negeri untuk memperoleh penetapan. Setelah menerima penetapan, penyidik menerbitkan penetapan penghentian penyidikan. Setelah memperoleh penetapan dari Pengadilan Negeri, para pihak diperintahkan untuk melaksanakan kesepakatan diversi. Waktu pelaksanaan kesepakatan diversi dimulai sejak dikeluarkannya penetapan dari Pengadilan Negeri.

Tabel 2

Data Diversi Yang Mencapai Kesepakatan dan Memperoleh Penetapan dari Pengadilan Negeri di Polres Kerinci Tahun 2016 S/D 2018

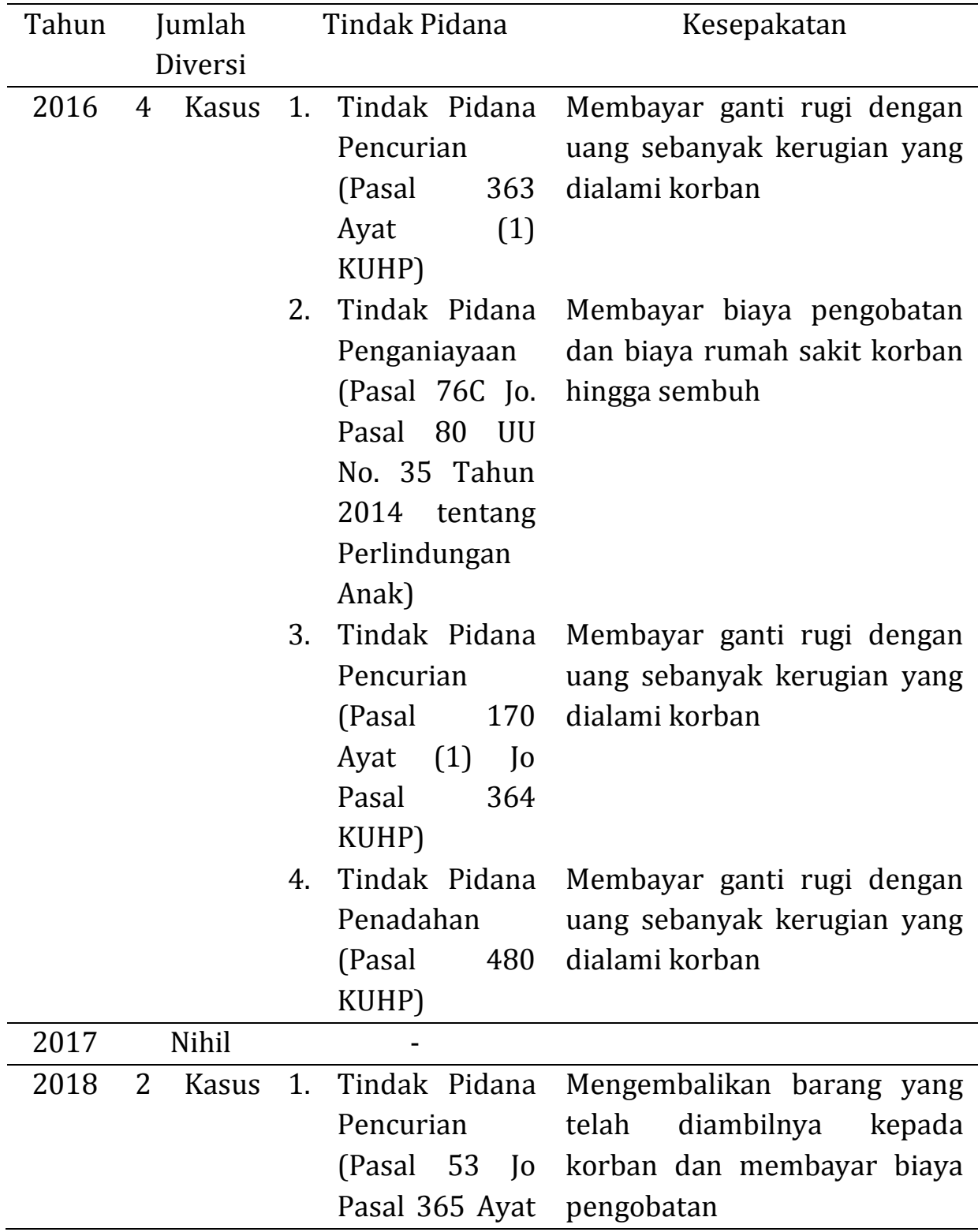

21 Wawancara Langsung, dengan Ragil, Polres Kerinci, Selasa 8 Januari 2019. 


\begin{tabular}{lll}
\hline 2. & (1) KUHP) & \\
& Tindak Pidana & Mengembalikan barang yang \\
& Pencurian & telah diambilnya kepada \\
& (Pasal 363 & korban dan membayar biaya \\
& Ayat (1) Ke 4 & pengobatan \\
KUHP) & \\
\hline
\end{tabular}

\section{Sumber Data: Penyidik Sat. PPA Polres Kerinci}

Dalam proses pelaksanaan kesepakatan diversi pada tingkat penyidikan di Polres Kerinci, pihak pelaku harus lebih utama meminta maaf kepada korban secara langsung dan berjanji tidak akan mengulanginya lagi. Selanjutnya dalam pelaksanaan pengembalian keadaan semula atau ganti kerugian, dilakukan setelah dikeluarkannya penetapan dari Pengadilan Negeri yang dilakukan antara pihak pelaku dan pihak korban.

Untuk tenggang waktu pelaksanaan kesepakatan diversi tidak dijelaskan secara eksplisit baik pada UU No. 11 Tahun 2012 tentang Sistem Peradilan Pidana Anak maupun pada PP No. 065 Tahun 2015 tentang Pedoman Pelaksanaan Diversi dan Penanganan Anak yang Belum Berumur 12 Tahun, akan tetapi ditetapkan pada kesepakatan diversi yang telah disepakati para pihak.

Tenggang waktu pelaksanaan kesepakatan diversi memang tidak semua ditentukan dalam musyawarah diversi, tetapi hanya beberapa perkara saja. Dalam hal ini ketentuan tenggang waktu dalam pelaksanaan kesepakatan diversi hanya disebutkan secara lisan oleh pihak korban kepada pihak pelaku. Dalam hal tenggang waktu pelaksanaan kesepakatan diversi sebaiknya disebutkan didalam berita acara kesepakatan diversi sehingga akan lebih jelas oleh para pihak terkait tenggang waktu pelaksanaan kesepakatan diversi.

Dalam pelaksanaan kesepakatan diversi penyidik tidak ikut serta atau melihat langsung pihak pelaku membayar ganti rugi kepada pihak korban. Setelah proses diversi selesai maka dilaksanakannya pembayaran ganti rugi diserahkan sepenuhnya pada pihak pelaku dan pihak korban. Penyidik tidak melakukan pengawasan secara langsung dalam proses pembayaran ganti rugi. Dapat dikatakan pula bahwa penyidik tidak melakukan pengawasan langsung dalam pelaksanaan kesepakatan diversi. Sehingga tidak menutup kemungkinan adanya kelalaian oleh pelaku dalam membayar ganti rugi kepada korban. Seperti yang dikemukakan oleh Ragil (Kanit PPA) Polres Kerinci bahwa: Setelah dilakukannya diversi maka ganti rugi yang harus dibayarkan oleh pelaku tidak menjadi tanggung jawab penyidik. Pembayaran ganti rugi yang akan dibayarkan oleh pelaku langsung kepada pihak korban dilakukan tanpa adanya pihak lain sebagai perantara termasuk tanpa adanya penyidik. ${ }^{22}$

Selain itu terdapat pula pembayaran ganti rugi yang dilakukan langsung pada saat proses diversi dimana pada hari pihak korban dan pihak pelaku dipertemukan. Dikarenakan pihak korban dan pihak pelaku telah sepakat sebelumnya untuk menyelesaikan perkara pidana tersebut secara damai dan telah membicarakan persoalan ganti rugi yang ingin diminta oleh korban. Seperti yang dikemukakan oleh Ragil (Kanit PPA) Polres Kerinci bahwa: Pembayaran ganti rugi juga ada yang

22 Wawancara Langsung, dengan Iptu Ragil, Polres Kerinci, Selasa 8 Januari 2019. 
dilakukan langsung pada saat proses diversi, hal ini dikarenakan pihak korban dan pihak pelaku telah dipertemukan sebelumnya dan ditanyakan kesediaannya untuk menyelesaikan perkara pidana tersebut dengan diversi, setelah disetujui pada saat diadakannya proses diversi pihak pelaku langsung membayar ganti rugi yang telah dibicarakan sebelumnya. ${ }^{23}$ Pembayaran ganti rugi secara langsung pada saat diadakan diversi sangat berguna untuk menghindari adanya kelalaian pihak pelaku untuk membayar ganti rugi kepada pihak korban.

Jika kesepakatan diversi tidak dilaksanakan, maka pihak korban dapat menyampaikan kepada Pembimbing Kemasyarakatan. Pembimbing Kemasyarakatan segera membuat laporan kepada penyidik bahwa kesepakatan diversi tidak dilaksanakan. ${ }^{24}$ Pihak korban dapat melanjutkan proses hukum apabila pelaku tidak melaksanakan kesepakatan yang telah disepakati.

Dalam hal kesepakatan diversi tidak dilaksanakan sesuai waktu yang ditentukan, selain melanjutkan proses hukum, korban dan pelaku menyelesaikan kesepakatan diversi secara kekeluargaan dengan melibatkan lembaga adat. Seperti yang disampaikan oleh Iptu Ragil (Kanit PPA) Polres Kerinci: Dalam hal pelaksanaan ganti rugi sesuai kesepakatan diversi diserahkan sepenuhnya kepada pihak pelaku dan korban, penyidik hanya bertanggungjawab dalam proses diversi, setelah diversi selesai pemenuhan pelaksanaan ganti rugi diserahkan sepenuhnya kepada pihak pelaku dan korban. Apabila pelaku tidak memenuhi kesepakatan diversi sesuai waktu yang telah ditentukan, maka pihak pelaku dan pihak korban boleh menyelesaikannya secara kekeluargaan tanpa melibatkan penyidik. ${ }^{25}$ Kesepakatan diversi yang tidak dilaksanakan sesuai waktu yang telah ditentukan akan dilanjutkan ke proses peradilan pidana, hal ini tidak sesuai dengan pelaksanaan kesepakatan diversi pada tingkat penyidikan di Polres Kerinci.

Jika pelaku tidak dapat melaksanakan kesepakatan yang telah disepakati maka proses diversi dianggap gagal. Jika diversi gagal maka proses pemeriksaan perkara pidana anak akan dilanjutkan ke proses peradilan.

Menurut penulis dalam hal pelaksanaan kesepakatan diversi jika tidak dilaksanakan atau tidak dilaksanakan menurut tenggang waktu yang disepakati maka proses peradilan pidana terhadap anak harus dilanjutkan. Sehingga tidak merugikan pihak korban yang mengalami kerugian akibat perbuatan pidana yang dilakukan anak. Hal ini sesuai dengan peraturan yang telah ditentukan dan penegak hukum juga harus lebih tegas demi kepentingan pihak yang terlibat.

\section{Kendala Yang Dihadapi dalam Pelaksanaan Kesepakatan Diversi Pada Tingkat Penyidikan}

Kendala-kendala yang dihadapi oleh penyidik maupun pihak yang bersangkutan dalam pelaksanaan kesepakatan diversi pada tingkat penyidikan dalam Sistem Peradilan Pidana, terhadap kesepakatan diversi yang berhasil dilaksanakan dan yang tidak dapat dilaksanakan.

1. Sulitnya untuk mendapatkan kesepakatan kedua pihak

Wawancara Langsung, dengan Iptu Ragil, Polres Kerinci, Selasa 8 Januari 2019.

R. Wiyono, Loc.Cit.

Wawancara Langsung, dengan Iptu Ragil, Polres Kerinci, Selasa 8 Januari 2019. 
Adapun sedikit kendala selama mengupayakan penerapan kesepakatan diversi terhadap perkara pidana yang melibatkan anak, Menurut Iptu Ragil (Kanit PPA) Polres Kerinci mengemukakan bahwa: Pada awalnya terdapat kesulitan dalam mencapai kesepakatan antar pihak yang terlibat dalam perkara pidana anak. Hal ini disebabkan karena antar pihak tidak mau mengalah dalam hal persoalan ganti rugi terjadinya perkara pidana. Namun dengan adanya masukan dari pihak penyidik, antar pihak mau menerima hasil kesepakatan. ${ }^{26}$

Pelaksanaan kesepakatan diversi yang sulit ditangani adalah dalam hal ganti rugi. Menurut pihak korban, ganti rugi yang diberikan oleh pelaku tidak sesuai dan tidak seimbang atas tindak pidana yang telah dilakukannya. Sedangkan menurut pihak pelaku, ganti rugi yang diminta oleh korban sangat berat sehingga memberatkan pelaku untuk melaksanakannya. Dalam proses diversi pihak korban dan pelaku selalu memperdebatkan persoalan masalah ganti rugi sehingga sedikit menyulitkan bagi penyidik untuk menyelesaikan proses diversi.

2. Sulitnya mempertemukan kedua belah pihak dalam proses diversi

Selain persoalan ganti rugi, Penyidik juga mengalami kendala dalam hal mempertemukan pihak korban dan pihak pelaku dalam proses diversi. Seringkali pihak yang bersangkutan tidak dapat menghadiri proses musyawarah diversi, sehingga menjadi penghambat untuk menyelesaikan proses diversi. Seperti yang dikemukakan oleh Ragil (Kanit PPA) Polres Kerinci, bahwa: Pihak pelaku dan pihak korban terkadang sangat sulit untuk dipertemukan dengan alasan kesibukan masing-masing, hal ini tentu saja menjadi kendala dalam melaksanakan proses diversi. Jika proses diversi tetap dilaksanakan tanpa kehadiran salah satu pihak, bisa saja kesepakatan yang sepakati dalam proses diversi tidak diterima oleh salah satu pihak. ${ }^{27}$

Dalam proses diversi bisa saja dilakukan tanpa kehadiran orang tua salah satu pihak akan tetapi kesepakatan yang dicapai dalam proses diversi bisa saja tidak sesuai dengan apa yang diinginkan oleh salah satu pihak. Pihak korban tidak dapat menghadiri pertemuan yang telah dipersiapkan penyidik sebelum proses diversi sehingga pertemuan tersebut ditunda dan proses diversi pun juga harus ditunda. Dikarenakan sulitnya mempertemukan kedua belah pihak, proses diversi untuk mencapai kesepakatan pun tidak dapat dilakukan.

3. Lalainya pelaku dalam melaksanakan pembayaran ganti rugi kepada korban

Pihak pelaku terkadang lalai dalam memenuhi haknya untuk membayar ganti rugi kepada korban, hal ini pastinya sangat menyulitkan bagi pihak korban. Terkadang pihak pelaku juga tidak melaksanakan pembayaran ganti rugi sesuai waktu yang telah ditentukan. Seperti yang dikemukakan oleh Iptu Ragil (Kanit PPA) Polres Kerinci, bahwa: Pihak pelaku terkadang tidak membayar ganti rugi sesuai waktu yang telah ditentukan. Hal ini tentu saja meresahkan korban, karena pelaku tidak juga membayar ganti rugi setelah waktu yang ditentukan. Tetapi korban tidak ingin melanjutkan proses perkara tersebut sehingga diselesaikan secara kekeluargaan antara pihak pelaku dan pihak korban. ${ }^{28}$

Dalam hal ini menurut penulis, dalam pelaksanaan kesepakatan diversi penyidik harus lebih tegas dalam proses diversi untuk mencapai kesepakatan yang

26 Wawancara Langsung, dengan Ragil, Polres Kerinci, Selasa 8 Januari 2019.

27 Wawancara Langsung, dengan Ragil, Polres Kerinci, Selasa 16 April 2019.

28 Wawancara Langsung, dengan IPTU RAGIL, Polres Kerinci, Selasa 16 April 2019. 
tidak hanya meringankan korban akan tetapi juga tidak terlalu memberatkan pelaku sehingga pelaksanaan kesepakatan diversi bisa berjalan dengan baik. Dan perlu adanya pengawasan dari penegak hukum untuk menghindari adanya kelalaian dari pihak pelaku dalam melaksanakan pembayaran ganti rugi. Pihak pelaku juga harus melaksanakan kesepakatan sesuai waktu yang telah ditentukan, karena kesepakatan diversi adalah hasil dari musyawarah yang telah disepakati oleh pihak pelaku dan pihak korban yang artinya pihak pelaku menyetujui kesepakatan tersebut serta sanggup melaksanakan kesepakatan diversi tersebut.

4. Permintaan ganti rugi yang besar

Ganti rugi yang diajukan oleh pihak korban seharusnya sesuai dengan kerugian yang benar-benar dialami oleh korban karena tindak pidana. Korban dalam mengajukan ganti rugi juga sebaiknya memperhatikan kondisi ekonomi keluarga pelaku. Hal ini menjadi salah satu kendala dalam berhasilnya diversi, karena pelaku merasa tidak dapat melaksanakan kesepakatan ganti rugi dengan biaya ganti rugi yang besar.

Pihak korban dalam menuntut ganti rugi kepada pelaku harus memperhatikan kondisi pelaku dan tidak hanya mementingkan diri sendiri, hal ini menjadi salah satu penyebab gagalnya diversi.

\section{Kesimpulan}

Proses pelaksanaan kesepakatan diversi pada tingkat penyidikan dalam Sistem Peradilan Pidana khususnya di Polres Kerinci dari tahun 2016 sampai 2018 dilaksanakan berdasarkan Undang-Undang Nomor 11 Tahun 2012 tentang Sistem Peradilan Pidana Anak dan para penegak hukum tidak terlalu fokus terhadap Peraturan Pemerintah Nomor 65 Tahun 2015 tentang Pedoman Pelaksanaan Diversi dan Penanganan Anak yang Belum Berumur 12 (dua belas) Tahun. Dengan adanya UU SPPA penegak hukum merasa cukup dan hanya terpaku pada UU SPPA saja. Tetapi pada pelaksanaannya masih terdapat beberapa hal yang tidak sesuai dengan peraturan yang ada dalam pelaksanaan kesepakatan diversi tersebut.

Ada beberapa kendala dalam proses pelaksanaan kesepakatan diversi diantaranya: penyidik mengalami kesulitan dalam mempertemukan pihak korban dan pihak pelaku. Dalam proses pelaksanaan diversi antar kedua pihak sering memperdebatkan masalah ganti kerugian sehingga sedikit mempersulit jalannya proses diversi. Selain itu kendala lain yang dihadapi adalah lalainya pihak pelaku dalam membayar ganti rugi kepada pihak korban. Serta pihak korban terkadang meminta ganti rugi yang besar kepada pelaku, hal ini tentunya memberatkan pelaku dan dapat mengakibatkan gagalnya proses diversi.

\section{DAFTAR PUSTAKA}

\section{Dokumen Hukum}

Republik Indonesia. Undang-Undang Tentang Sistem Peradilan Pidana Anak. UU Nomor 11 Tahun 2012. LNRI Tahun 2012 Nomor 153. TLNRI Nomor 5332.

Republik Indonesia. Peraturan Pemerintah Republik Indonesia Tentang Pedoman Pelaksanaan Diversi Dan Penanganan Anak Yang Belum Berumur 12 (Dua Belas) Tahun. PP Nomor 65 Tahun 2015. LNRI Tahun 2015 Nomor 194. TLNRI Nomor 5732 . 


\section{Buku}

Gultom, Maidin. "Perlindungan Hukum Terhadap Anak (dalam Sistem Peradilan Pidana Anak di Indonesia)". Bandung: PT. Refika Aditama, cetakan ketiga, 2014.

Husin, Kadri dan Budi Rizki Husin. "Sistem Peradilan Pidana di Indonesia". Jakarta: Sinar Grafika, 2016.

Marlina. "Pengantar Konsep Diversi dan Restorative Justice dalam Hukum Pidana". Medan: USU Press.

Muladi. "Kapita Selekta Hukum Pidana”. Semarang: Penerbit Universitas Diponegoro, 1995.

Mulyadi, Lilik. "Pengadilan Anak di Indonesia (Teori, Praktik, dan Permasalahannya)". Bandung: Mandar Maju, 2005.

Nasir, M. Jamil. “Anak Bukan Untuk Dihukum”. Jakarta: Sinar Grafika Offset, cetakan kedua, 2013.

Bambang Waluyo. "Pidana dan Pemidanaan”. Jakarta: Sinar Grafika, 2004.

Wiyono, R. "Sistem Peradilan Pidana Anak di Indonesia". Jakarta: Sinar Grafika Offset, 2016.

Sinaga, Dahlan. "Penegakan Hukum Dengan Pendekatan Diversi".Yogyakarta: Nusa Media Yogyakarta, 2017.

JURNAL

A. Basronni, Pertanggungjawaban Pidana Yang Dilakukan Oleh Anak, http://eprints.ums.ac.id/52012/3/BAB\%201.pdf, di akses pada hari Selasa tanggal 15 Januari 2019 pukul 10.32 .

Hafrida, Yulia Monita, dan Elisabeth Siregar. "Pembinaan Narapidana Anak Di Lembaga Pemasyarakatan Anak. Sei. Bulu Muara Bulian (Kajian Terhadap Proses Penyelesaian Perkara Pidana Anak Tanpa Pidana Penjara (Diversi) Menurut Undang-Undang Nomor 11 Tahun 2012 Tentang Sistem Peradilan Pidana Anak)". Jurnal Publikasi Pendidikan, September 2015.

Sri Rahayu. "Diversi Sebagai Alternatif Penyelesaian Perkara Tindak Pidana Yang Dilakukan Anak Dalam Perspektif Sistem Peradilan Pidana Anak". Jurnal Ilmu Hukum, Jambi, 2015.

Nur Rochaeti. "Implementasi Keadilan Restoratif Dan Pluralisme Hukum Dalam Sistem Peradilan Pidana Anak Di Indonesia”. Hasil Penelitian, Fakultas Hukum Diponegoro, Semarang, 2015.

Saija, F. Willem dan Budi Suhariyanto. "Laporan Penelitian (Pelaksanaan Diversi Di Tingkat Pengadilan Negeri Dalam Sistem Peradilan Pidana Anak)”, 2016.

Satriani, Riska Vidya. "Keadilan Restoratif Sebagai Tujuan Pelaksanaan Diversi Pada Sistem Peradilan Pidana Anak", https://www.mahkamahagung.go.id/id/artikel /2613/keadilan-restoratif- 
sebagai-tujuan-pelaksanaan-diversi-pada-sistem-peradilan-pidana-anak, di akses pada hari Jum'at tanggal 04 Desember 2018 pukul 13.48.

Utami, Pangestika Rizki. "Konsep Diversi Dan Restorative Justice Sebagai Pergeseran Tanggung Jawab Pidana Pada Sistem Peradilan Pidana Anak”, IAIN Purwokerto, 2018. 